\title{
Sickle Cell-Hemoglobin E Disease
}

National Cancer Institute

\section{Source}

National Cancer Institute. Sickle Cell-Hemoglobin E Disease. NCI Thesaurus. Code C155307.

A variant of sickle cell disease due to heterozyg osity for hemoglobin $\mathrm{S}$ and hemoglobin $\mathrm{E}$ mutations. Patients present with the symptoms of sickle cell disease but the symptoms are less frequent and severe compared to patients with hemoglobin SS disease. 